\title{
Mutation analysis of tumor suppressor gene $P T E N$ in patients with gastric carcinomas and its impact on PI3K/AKT pathway
}

\author{
YU-GANG WEN ${ }^{1 *}$, QUAN WANG ${ }^{1 *}$, CHONG-ZHI ZHOU $^{1}$, GUO-QIANG QIU ${ }^{1}$, \\ ZHI-HAI PENG ${ }^{1}$ and HUA-MEI TANG ${ }^{2}$ \\ Departments of ${ }^{1}$ General Surgery and ${ }^{2}$ Pathology, Affiliated First People's Hospital, \\ College of Medicine, Shanghai Jiao Tong University, Shanghai 200080, P.R. China
}

Received February 23, 2010; Accepted April 1, 2010

DOI: $10.3892 /$ or_00000832

\begin{abstract}
The aim of this study was to clarify the participation of PTEN mutation in gastric carcinogenesis and its impact on PI3K/AKT pathway. All nine exons of PTEN were screened for mutations by direct sequencing in 144 patients with pathologically proven gastric carcinoma and their corresponding normal mucosae, followed by Western blotting to detect the changes in PI3K/AKT pathway. Direct sequencing indicated there were 27 cases with mutations among 144 patients consisting of 15 cases $(55.6 \%)$ of missense mutation, nine nonsense mutations (33.3\%), two 1-bp deletion $(7.4 \%)$, and a mutation within intron $6(3.7 \%)$. The mutation hot spots at codons 36, 75, 232 and 393 had not been observed previously, and the mutation sites in exons 3, 5, 6 and 8 were not found, suggesting that there might be some unique characteristic of PTEN inactivation mechanism in the Shanghai population. The PTEN mutation rate was significantly higher at pTMN stages III and IV than that at stages I and II $(\mathrm{P}<0.005)$, and it was higher in poorly differentiated gastric cancer than in well or moderately differentiated types $(\mathrm{P}<0.05)$. PTEN and E-cadherin protein expression in gastric cancer was significantly down-regulated comparing with that in paracancerous tissues, while the PI3K, AKT, MMP-2, MMP-9 and NF- $\mathrm{KBp} 65$ protein were overexpressed in cancer tissues. Our results implicated that the mutations of PTEN did not occur at a significant rate in gastric carcinoma in Shanghai, but might play a role in tumorigenesis. The mutation status of PTEN was significantly relevant to pTNM
\end{abstract}

Correspondence to: Dr Hua-Mei Tang or Professor Zhi-Hai Peng, Department of Pathology, Affiliated First People's Hospital, College of Medicine, Shanghai Jiao Tong University, 85 Wujin Road, Shanghai 200080, P.R. China

E-mail: tanghuamei@gmail.com

E-mail: pengpzh@hotmail.com

*Contributed equally

Key words: PTEN, tumor suppressor gene, gene mutation, gastric carcinoma staging and degree of cell differentiation, hinting that PTEN might be a prognostic biomarker of gastric cancer. The decreased expression of PTEN and E-cadherin, together with the overexpression of PI3K, AKT, MMP-2, MMP-9 and $\mathrm{NF}-\kappa \mathrm{Bp} 65$, contributed cooperatively to the accelerated progress of gastric cancer.

\section{Introduction}

Despite the declining incidence of gastric cancer over the past decade, it is still the second most common fatal malignancy worldwide (1). In Shanghai, gastric cancer is the second major cause of cancer-related death among males and the third major cause of cancer-related death among females. There are about 5000 new cases diagnosed every year, with over 4000 patients died annually from this disease $(2,3)$. The genetic bases underlying gastric tumorigenesis and progression are largely unknown. Recently, much progress has been made in identifying genes involving in the development of gastric cancer, which is useful for understanding the pathogenesis of gastric cancer and defining its molecular signature.

In the past ten years, we have used some high-throughput methods to fully examine the gene expression patterns in gastric cancer, including LOH (loss of heterozygosity) and wide-genome expression microarray. A candidate tumor suppressor gene, PTEN (phosphatase and tensin homologue deleted on chromosome ten/mutated in multiple advanced cancers 1), has been screened. The PTEN gene locates on human chromosome band 10q23.31, contains nine exons and encodes a 403-amino acid, dual-specificity phosphatase with homology to the cytoskeleton proteins chicken tensin and bovine auxilin, cytoskeletal proteins that interact with adhesion molecules (4-8). Mutations of PTEN gene have been found in a variety of human cancer cell lines and primary tumors of the endometrium, brain, prostate, breast and kidney in different frequencies (9-17), indicating the gene might play a role in the tumorigenesis of some cancers. Furthermore, it was reported that the PTEN gene might regulate tumor cell invasion and metastasis $(8,18,19)$. Thus, this gene is probably correlated with some human cancer progression $(11,20,21)$. However, the role of PTEN mutation in the development of human gastric cancer and the molecular mechanisms under- 
Table I. Oligonucleotide primers for PTEN analysis.

\begin{tabular}{|c|c|c|c|}
\hline Exon & Sequence & Annealing temperature $\left({ }^{\circ} \mathrm{C}\right)$ & Product size (bp) \\
\hline 1 & $\begin{array}{l}\text { Forward: 5'-CTCCTCCTTTTTCTTCAGCC-3' } \\
\text { Reverse: 5'-TATGACCTAGCAACCTGACCA-3' }\end{array}$ & 56 & 253 \\
\hline 2 & $\begin{array}{l}\text { Forward: 5'-TGACCACCTTTTATTACCA-3' } \\
\text { Reverse: 5'-AAGTATCTTTTTCTGTGGCTTA-3' }\end{array}$ & 48 & 242 \\
\hline 3 & $\begin{array}{l}\text { Forward: 5'-ATAGAAGGGGTATTTGTTGGA-3' } \\
\text { Reverse: 5'-ACCTCACTCTAACAAGCAGATA-3' }\end{array}$ & 56 & 293 \\
\hline 4 & $\begin{array}{l}\text { Forward: 5'-TTCAGGCAATGTTTGTTA-3' } \\
\text { Reverse: 5'-CTCGATAATCTGGATGACTCA-3' }\end{array}$ & 48 & 225 \\
\hline 5 & $\begin{array}{l}\text { Forward: 5'-GCAACATTTCTAAAGTTACCTA-3' } \\
\text { Reverse: 5'-TCTGTTTTCCAATAAATTCTC-3' }\end{array}$ & 48 & 376 \\
\hline 6 & $\begin{array}{l}\text { Forward: 5'-GAGTAACTATTCCCAGTCAGA-3' } \\
\text { Reverse: 5'-TAATTTGTTCAAATGCTTCAGA-3' }\end{array}$ & 54 & 286 \\
\hline 7 & $\begin{array}{l}\text { Forward: 5'-ATCGTTTTTGACAGTTTG-3' } \\
\text { Reverse: 5'-CCAATGAAAGTAAAGTACA-3' }\end{array}$ & 48 & 260 \\
\hline 8 & $\begin{array}{l}\text { Forward: 5'-AGGTGACAGATTTTCTTTTTTA-3' } \\
\text { Reverse: 5'-TAGCTGTACTCCTAGAATTA-3' }\end{array}$ & 52 & 384 \\
\hline 9 & $\begin{array}{l}\text { Forward: 5'-GTTCATCTGCAAAATGGA-3' } \\
\text { Reverse: 5'-TGGTAATCTGACACAATGTCCTA-3' }\end{array}$ & 50 & 397 \\
\hline
\end{tabular}

lying the roles of the PTEN/PI3K/AKT pathway during gastric tumorigenesis remain poorly defined.

In the present study, we examined the mutation frequency and pattern of the PTEN gene in primary gastric cancer specimens by direct sequencing of all exons and flanking regions, then identified its associated gene expression using Western blot analysis. We observed mutations of PTEN in 27 of 144 $(18.75 \%)$ patients with gastric cancer, showing some hot spot mutation sites, suggesting that the PTEN gene might have a critical role in the pathogenesis of human gastric cancer.

\section{Materials and methods}

Tissue samples and DNA extraction. Between January 2007 and April 2008, 144 consecutive patients with gastric carcinoma that underwent surgical resection at the Department of Surgery of Shanghai Jiao Tong University Affiliated First People's Hospital were enrolled in this study. There were 79 males, 65 females (average age, 65 years; ranging from 31-85 years), including all of the stages and histological types of gastric cancer. All patients were proven to have a primary adenocarcinoma of the stomach with no evidence of any other malignancy. None of the patients received preoperative chemotherapy and/or radiation therapy. Clinicopathological descriptions were carried out according to the Japanese Research Society for Gastric Cancer (JRSGC) standards (22). The cancer tissues with their matched normal tissues were collected immediately after surgical resection, frozen instantly in liquid nitrogen, and then stored at $-80^{\circ} \mathrm{C}$ until analyzed. Genomic DNA was isolated from frozen primary gastric cancer and the paired normal tissues using the proteinase-K (Stratagene, La Jolla, CA) digestion and phenol/ chloroform extraction procedures according to the method by Sambrook et al (23). The protocols used in the studies were approved by the Hospital's Protection of Human Subjects Committee. Patients whose surgical tissue was studied gave their written informed consent.

PCR amplification. Tumor DNAs were subjected to PCR amplification. All nine exons of the PTEN gene were amplified using primers designed and synthesized by Invitrogen (Shanghai) Corp. (Table I). PCR amplification was performed within a reaction mixture containing 10X PCR Buffer $2.5 \mu \mathrm{l}\left(\mathrm{Mg}^{2+}\right.$ free, Promega Corp., Madison, WI), $\mathrm{Mg}^{2+} 0.8 \mu \mathrm{l}$ (50 mM), dNTP $0.5 \mu 1$ (10 mM, Promega), primer F $0.5 \mu 1$ $(10 \mu \mathrm{M})$, primer R $0.5 \mu \mathrm{l}(10 \mu \mathrm{M})$, Taq polymerase $0.2 \mu \mathrm{l}$ (5 U/ $\mu 1$, Promega), genomic DNA $1.0 \mu 1$ and $\mathrm{ddH}_{2} \mathrm{O} 19.0 \mu 1$. A programmable thermocycler (GeneAmp PCR System 9700, Applied Biosystems Inc., USA) was used to perform amplifications. The PCR condition for each exon was as follows: pre-denaturation $4 \mathrm{~min}$ at $95^{\circ} \mathrm{C}, 35$ cycles of $30 \mathrm{sec}$ denaturation at $95^{\circ} \mathrm{C}, 40 \mathrm{sec}$ annealing at temperature shown in Table I, $50 \mathrm{sec}$ extension at $72^{\circ} \mathrm{C}$, and $10 \mathrm{~min}$ final extension at $72^{\circ} \mathrm{C}$. The PCR products were loaded onto polyacrylamide gels of GeneGel Excel 12.5/24 kit (Pharmacia Biotech Inc., San Francisco, CA) using the Genephore electrophoresis unit (Pharmacia Biotech). Gels were run for $3 \mathrm{~h}$ at $38 \mathrm{~V}$.

DNA sequencing. The PCR products were purified using the QIAEX II Gel Extraction kit (Qiagen Inc., Valencia, CA) according to the manufacturer's instruction. Then mixed $1 \mu 1$ PCR gel recycling product, $1 \mu 1 \mathrm{BigDye}$ Mix (Applied Biosystems), $1 \mu 1$ sequencing primer, $2 \mu 1 \mathrm{ddH}_{2} \mathrm{O}$ into $0.2 \mathrm{ml}$ PCR tube, centrifuged briefly, and amplified again: $98^{\circ} \mathrm{C}$ 
A

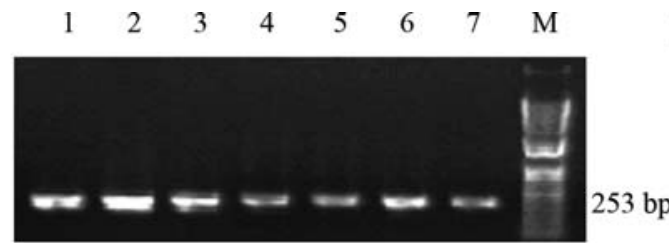

B

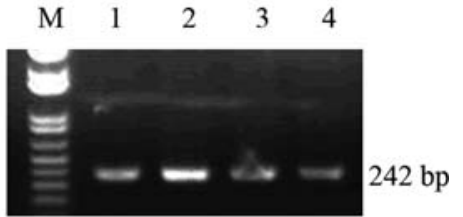

$\mathrm{C}$

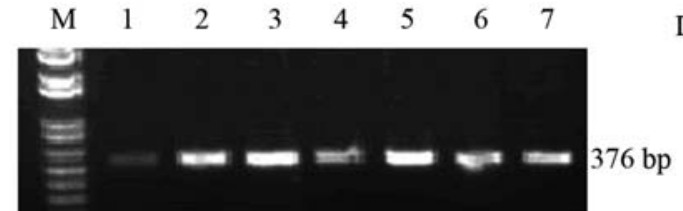

D

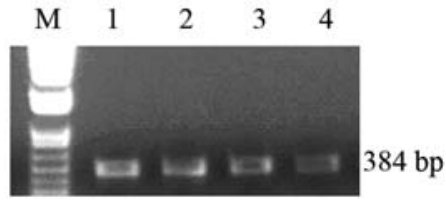

Figure 1. Part of the PCR amplification products detected by electrophoresis gel. (A) exon 1 at 253 bp. (B) exon 2 at 242 bp. (C) exon 5 at 376 bp. (D) exon 8 at 384 bp. M, marker; $1-7$, samples.

denaturation $2 \mathrm{~min}, 25$ cycles of $96^{\circ} \mathrm{C} 10 \mathrm{sec}, 50^{\circ} \mathrm{C} 5 \mathrm{sec}$, $60^{\circ} \mathrm{C} 4 \mathrm{~min}$, and ended at $4^{\circ} \mathrm{C}$. The products were purified one more time with $25 \mu 1$ sodium acetate/ethanol, votexing, put on ice $10 \mathrm{~min}, 4^{\circ} \mathrm{C} 12000 \mathrm{~g}$ centrifuged $30 \mathrm{~min}$, the supernatant was discarded, followed by $50 \mu 170 \%(\mathrm{~V} / \mathrm{V})$ ethanol washing of sediment twice, $4^{\circ} \mathrm{C} 12000 \mathrm{~g}$ centrifuged for $5 \mathrm{~min}$, discarding supernatant, and vacuum drying for 10 $15 \mathrm{~min}$. Then $12 \mu \mathrm{l}$ TSR was added, votexed thoroughly to dissolve the DNA sediment, centrifuged briefly, and the sample was heated to $95^{\circ} \mathrm{C}$ for $2 \mathrm{~min}$, snap-cooled on ice and loaded onto the sequencing gel.

An automated DNA electrophoresis system (Model 3730, Applied Biosystems) with a laser diode emitting at $785 \mathrm{~nm}$ and fluorescence detection between 815 and $835 \mathrm{~nm}$ was used to detect and analyze the sequencing ladder. Electrophoresis was performed on a $41 \mathrm{~cm} \times 25 \mathrm{~cm} \times 0.2 \mathrm{~mm}$ gel consisting of $6 \%$ Long Ranger gel matrix (AT Biochem; Malvern, PA) with $7 \mathrm{M}$ urea and a running buffer consisting of $133 \mathrm{mM}$ Tris base, $44 \mathrm{mM}$ boric acid and $2.5 \mathrm{mM}$ EDTA, $\mathrm{pH} 9$ at $50^{\circ} \mathrm{C}$. Following the loading of samples, electrophoresis was carried out at $1.2 \mathrm{kV}$ constant voltage $25 \mathrm{~min}, 7.5 \mathrm{kV}$ $2 \mathrm{~h}$, with the gel heated to $50^{\circ} \mathrm{C}$. The PCR products were sequenced directly from both forward and reverse directions. Data collection and image analysis utilized the software supplied with the model 3730 DNA sequencer.

Western blotting. The tissues of gastric cancer or matched normal mucosa were cut into pieces, then homogenized in lysis buffer (50 mM Tris-HCl, $0.1 \%$ SDS, $150 \mathrm{mM} \mathrm{NaCl}$, $100 \mathrm{mg} / \mathrm{ml}$ phenylmethylsulfonyl fluoride, $1 \mathrm{mg} / \mathrm{ml}$ aprotinin, $1 \% \mathrm{NP}-40$ and $0.5 \%$ sodium orthovanadate) $200 \mu \mathrm{l} / 20 \mathrm{mg}$ tissue sample, and incubated at $4^{\circ} \mathrm{C}$ for $30 \mathrm{~min}$, centrifuged at $12000 \mathrm{~g}$ for $20 \mathrm{~min}$. Concentration of total proteins in the supernatant was quantified by Bradford assay. Proteins (50 $\mu \mathrm{g} /$ lane) were electrophoresed on $10 \%$ SDS-polyacrylamide gels, then transferred onto PVDF membrane $(0.45 \mathrm{~mm}$, Millipore, USA) in $25 \mathrm{mM}$ Tris-base, $190 \mathrm{mM}$ glycine and $20 \%$ methanol using a wet blotter (Bio-Rad, USA). Followed by blocking with 5\% fat-free milk in PBS for $2 \mathrm{~h}$, the membrane was incubated with anti-PTEN (Abcam, 1:500), anti-Akt (Santa Cruz, 1:200), anti-p-Akt (Santa Cruz, 1:100), anti-E-cadherin (Santa Cruz, 1:200), anti-MMP-2 (Santa Cruz, 1:500), antiMMP-9 (Santa Cruz, 1:500) and anti-GAPDH (Santa Cruz,

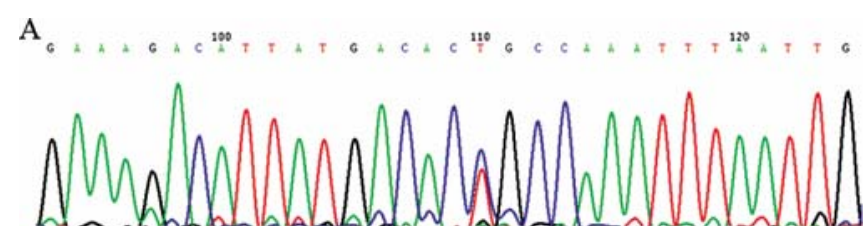

B

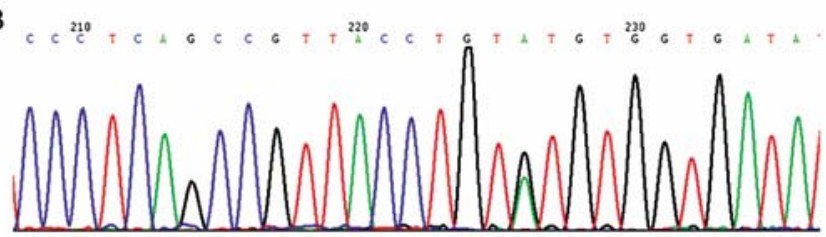

C

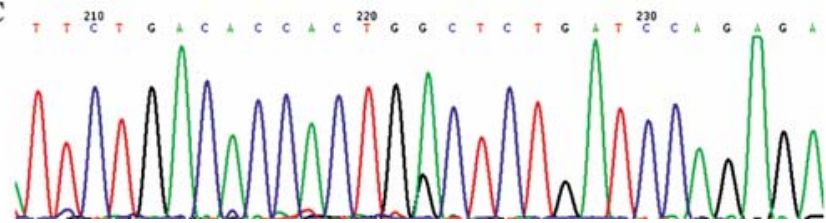

Figure 2. The chromatograms of part of the mutant exons. (A) exon 4, base $\mathrm{C} \rightarrow \mathrm{T}$ at 110. (B) exon 7, base $\mathrm{G} \rightarrow \mathrm{A}$ at 226. (C) exon 9, base $\mathrm{A} \rightarrow \mathrm{G}$ at 222 .

1:2000) at $4^{\circ} \mathrm{C}$ overnight, respectively. After binding of horseradish peroxidase (HRP)-coupled goat anti-mouse or goat anti-rabbit IgG (Santa Cruz, 1:2000) at room temperature for $2 \mathrm{~h}$ with gently shaking, antigens were visualized by enhanced chemiluminescence (ECL-kit, Millipore Biotechnology). All results are representatives of three independent experiments.

Statistical analysis. The $\chi^{2}$ test for proportion was used, as appropriate, to analyze the relationship between PTEN gene mutation rate and clinicopathological parameters. $\mathrm{P}<0.05$ was considered to be statistically significant. Analyses were performed using the SPSS statistical software program version 13.0 (SPSS Inc., Chicago, IL).

\section{Results}

All of the gastric cancers and their adjacent normal gastric tissues were screened for mutations of the PTEN gene in nine 
Table II. Mutations of PTEN in gastric cancer and clinicopathological features.

\begin{tabular}{|c|c|c|c|c|c|c|c|c|c|c|}
\hline $\begin{array}{l}\text { Case } \\
\text { no. }\end{array}$ & Gender & $\begin{array}{c}\text { Age } \\
\text { (years) }\end{array}$ & $\mathrm{pT}$ & $\mathrm{pN}$ & Stage $^{a}$ & Histology & Exon & $\begin{array}{l}\text { Mutated } \\
\text { codon }\end{array}$ & $\begin{array}{c}\text { Base } \\
\text { substitution }\end{array}$ & $\begin{array}{c}\text { Amino acid } \\
\text { change }\end{array}$ \\
\hline 4 & Male & 65 & $\mathrm{~T} 3$ & N3 & III & PD & 9 & Codon 380 & $\mathrm{GAC} \rightarrow \mathrm{GGC}$ & Asp $\rightarrow$ Gly \\
\hline 17 & Female & 72 & $\mathrm{~T} 3$ & N3 & III & $\mathrm{PD}$ & 4 & Codon 77 & $1 \mathrm{bp}$ deletion & Ile $\rightarrow$ Phe \\
\hline 20 & Male & 74 & $\mathrm{~T} 2$ & N3 & III & Mucinous & 7 & Codon 232 & $\mathrm{ACA} \rightarrow \mathrm{ACG}$ & $\begin{array}{l}\text { Nonsense } \\
\text { mutation }\end{array}$ \\
\hline 24 & Male & 69 & $\mathrm{~T} 3$ & N3 & III & MD & 9 & Codon 341 & $\mathrm{GCT} \rightarrow \mathrm{GCG}$ & $\begin{array}{l}\text { Nonsense } \\
\text { mutation }\end{array}$ \\
\hline 28 & Male & 60 & $\mathrm{~T} 3$ & $\mathrm{~N} 2$ & III & Signet & 7 & Codon 249 & $\mathrm{GTG} \rightarrow \mathrm{GTA}$ & $\begin{array}{l}\text { Nonsense } \\
\text { mutation }\end{array}$ \\
\hline 31 & Female & 58 & $\mathrm{~T} 2$ & $\mathrm{~N} 2$ & II & WD & 2 & Codon 36 & $\mathrm{AGA} \rightarrow \mathrm{AAA}$ & $\operatorname{Arg} \rightarrow$ Lys \\
\hline 36 & Male & 63 & $\mathrm{~T} 2$ & N1 & I & PD & 9 & Codon 380 & $\mathrm{GAC} \rightarrow \mathrm{GGC}$ & Asp $\rightarrow$ Gly \\
\hline 51 & Female & 64 & $\mathrm{~T} 2$ & $\mathrm{~N} 2$ & II & $\mathrm{PD}$ & 9 & Codon 393 & $\mathrm{GCA} \rightarrow \mathrm{ACA}$ & $\mathrm{Ala} \rightarrow \mathrm{Thr}$ \\
\hline 60 & Male & 61 & $\mathrm{~T} 4$ & N3 & IV & MD & 2 & Codon 36 & $\mathrm{AGA} \rightarrow \mathrm{AAA}$ & $\operatorname{Arg} \rightarrow$ Lys \\
\hline 64 & Male & 67 & $\mathrm{~T} 3$ & N1 & III & WD & 7 & Codon 232 & $\mathrm{ACA} \rightarrow \mathrm{ACG}$ & $\begin{array}{l}\text { Nonsense } \\
\text { mutation }\end{array}$ \\
\hline 67 & Male & 59 & $\mathrm{~T} 3$ & N3 & III & MD & 9 & Codon 393 & $\mathrm{GCA} \rightarrow \mathrm{ACA}$ & $\mathrm{Ala} \rightarrow \mathrm{Thr}$ \\
\hline 70 & Female & 62 & $\mathrm{~T} 4$ & $\mathrm{~N} 2$ & III & PD & 4 & Codon 75 & $\mathrm{CGC} \rightarrow \mathrm{TGC}$ & $\mathrm{Arg} \rightarrow \mathrm{Cys}$ \\
\hline 72 & Male & 66 & $\mathrm{~T} 2$ & N3 & III & WD & 2 & Codon 36 & $\mathrm{AGA} \rightarrow \mathrm{AAA}$ & Arg $\rightarrow$ Lys \\
\hline 79 & Male & 68 & $\mathrm{~T} 2$ & $\mathrm{~N} 2$ & II & PD & 9 & Codon 393 & $\mathrm{GCA} \rightarrow \mathrm{ACA}$ & $\mathrm{Ala} \rightarrow \mathrm{Thr}$ \\
\hline 82 & Female & 67 & $\mathrm{~T} 4$ & N3 & IV & $\mathrm{PD}$ & 2 & Codon 36 & $\mathrm{AGA} \rightarrow \mathrm{AAA}$ & $\operatorname{Arg} \rightarrow$ Lys \\
\hline 85 & Male & 68 & $\mathrm{~T} 2$ & $\mathrm{~N} 2$ & II & WD & 7 & Codon 249 & GTG $\rightarrow$ GTA & $\begin{array}{l}\text { Nonsense } \\
\text { mutation }\end{array}$ \\
\hline 87 & Male & 78 & $\mathrm{~T} 2$ & $\mathrm{~N} 2$ & III & PD & 7 & Codon 232 & $\mathrm{ACA} \rightarrow \mathrm{ACG}$ & $\begin{array}{l}\text { Nonsense } \\
\text { mutation }\end{array}$ \\
\hline 95 & Female & 69 & $\mathrm{~T} 3$ & N1 & III & PD & 1 & Codon 11 & $\mathrm{AGA} \rightarrow \mathrm{AAA}$ & $\operatorname{Arg} \rightarrow$ Lys \\
\hline 96 & Male & 73 & $\mathrm{~T} 2$ & $\mathrm{~N} 2$ & II & WD & 1 & Codon 17 & $\mathrm{CAA} \rightarrow \mathrm{CAG}$ & $\begin{array}{l}\text { Nonsense } \\
\text { mutation }\end{array}$ \\
\hline 101 & Male & 58 & $\mathrm{~T} 3$ & $\mathrm{~N} 2$ & III & PD & 9 & Codon 341 & $\mathrm{GCT} \rightarrow \mathrm{GCG}$ & $\begin{array}{l}\text { Nonsense } \\
\text { mutation }\end{array}$ \\
\hline 106 & Female & 68 & $\mathrm{~T} 4$ & N1 & III & $\mathrm{PD}$ & 4 & Codon 77 & $1 \mathrm{bp}$ deletion & Ile $\rightarrow$ Phe \\
\hline 116 & Male & 69 & $\mathrm{~T} 2$ & $\mathrm{~N} 2$ & II & MD & 4 & Codon 75 & $\mathrm{CGC} \rightarrow \mathrm{TGC}$ & $\mathrm{Arg} \rightarrow \mathrm{Cys}$ \\
\hline 120 & Male & 66 & $\mathrm{~T} 3$ & $\mathrm{~N} 2$ & III & PD & 4 & Codon 75 & $\mathrm{CGC} \rightarrow \mathrm{TGC}$ & $\mathrm{Arg} \rightarrow \mathrm{Cys}$ \\
\hline 126 & Female & 55 & $\mathrm{~T} 3$ & $\mathrm{~N} 2$ & III & PD & 7 & Codon 232 & $\mathrm{ACA} \rightarrow \mathrm{ACG}$ & $\begin{array}{l}\text { Nonsense } \\
\text { mutation }\end{array}$ \\
\hline 135 & Male & 77 & $\mathrm{~T} 2$ & $\mathrm{~N} 2$ & II & MD & 4 & Codon 75 & $\mathrm{CGC} \rightarrow \mathrm{TGC}$ & Arg $\rightarrow$ Cys \\
\hline
\end{tabular}

a Staging according to Japanese Research Society for Gastric Cancer. pT, pathological depth of tumor invasion; pN, pathological status of lymph node metastasis; WD, well differentiated; MD, moderately differentiated; PD, poorly differentiated; Signet, signet ring cell.

exons using the PCR amplification, purification and direct sequencing analysis. The PCR amplification products were detected by electrophoresis gel (Fig. 1). The chroma-tograms of mutant exons are shown in Fig. 2. Twenty-seven patients $(18.75 \%)$ showed an apparent mutation between the cancer and its paired normal tissue. Of 27 such differences, 2 were detected in exon 1 (cases 95 and 96), 4 in exon 2 (cases 31, 60, 72 and 82), 6 in exon 4 (cases 17, 70, 106, 116, 120 and 135), 6 in exon 7 (case 20, 28, 64, 85, 87 and 126), 8 in exon 9 (cases 4, 24, 36, 51, 55, 67, 79 and 101), and 1 in intron 6 (Table II).

Direct sequencing analysis of the PTEN gene mutations revealed 15 cases of missense mutation, nine nonsense mutations, two 1-bp deletion and one mutation within the splice donor site of intron 6 (Table II). The results indicated that the mutation site in exon 1 were found to be at codon 11 $(\mathrm{AGA} \rightarrow \mathrm{AAA})$ in one case, leading to arginine to lysine substitution; at codon $17(\mathrm{CAA} \rightarrow \mathrm{CAG})$ in one cases, leading to nonsense mutation. Exon 2 was found to be at codon 36 (AGA $\rightarrow$ AAA) in four cases, all leading to arginine to lysine substitution. The mutation sites in exon 4 were found to be at codon 75 (CGC $\rightarrow$ TGC) in four cases, leading to arginine to cysteine substitution; at codon 77 (1 bp deletion) in two cases, resulting in a change from isoleucine to phenylalanine substitution. The mutation sites in exon 7 were found to be at codon 232 (ACA $\rightarrow$ ACG) in four cases, resulting in nonsense mutations, at codon 249 (GTG $\rightarrow$ GTA) in two cases, resulting in nonsense mutations. The mutation site in exon 9 was found 
Table III. Correlation between PTEN gene mutation and clinicopathological parameters in gastric cancer patients.

\begin{tabular}{|c|c|c|c|}
\hline Clinicopathological parameters & Total cases & Cases of mutation & P-value \\
\hline \multicolumn{4}{|l|}{ Differentiation extent } \\
\hline Well and moderate differentiation & 78 & 10 & $<0.05$ \\
\hline Poor differentiation & 55 & 13 & \\
\hline \multicolumn{4}{|l|}{ pTNM staging } \\
\hline I, II & 69 & 8 & $<0.005$ \\
\hline III, IV & 75 & 18 & \\
\hline
\end{tabular}

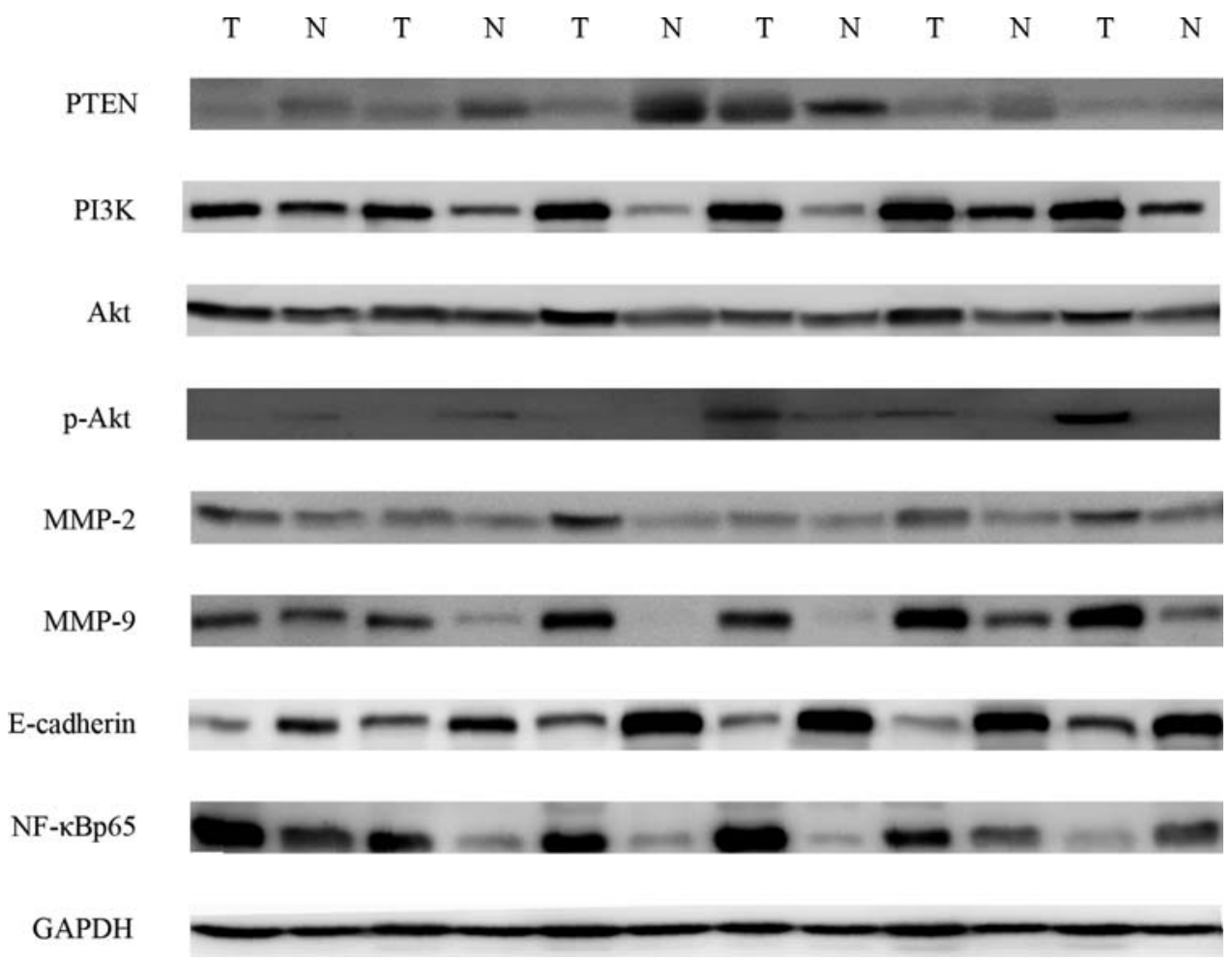

Figure 3. The protein expression of PTEN/PI3K/AKT pathway in gastric cancer detected by Western blot. With reduced expression of PTEN in gastric cancer, the overexpression of PI3K and AKT might inhibit E-cadherin expression, and promote expression of MMP-2, MMP-9 and NF-кBp65. T, tumor; N, nomal mucosa.

to be at codon $341(\mathrm{GCT} \rightarrow \mathrm{GCG})$ in two cases, resulting in nonsense mutations; at codon $380(\mathrm{CAC} \rightarrow \mathrm{GGC})$ in two cases, leading to aspartic acid to glycine substitution; at codon 393 ( $\mathrm{GCA} \rightarrow \mathrm{ACA})$ in four cases, leading to alanine to threonine substitution. The mutation site in intron 6 was found at $7 \mathrm{bp}$ upstream of 5' lateral exon $6(\mathrm{~T} \rightarrow \mathrm{G})$ in one case. The mutation sites in exon 3, 5, 6, 8 were not found. The PTEN gene mutation rate was significantly higher at pTMN stages III and IV than that at stages I and II $(\mathrm{P}<0.005)$, and it was higher in poorly differentiated gastric cancer than in well and moderately differentiated pathological types $(\mathrm{P}<0.05)$ (Table III).

Furthermore, Western blot detection showed a significantly reduced expression of PTEN and E-cadherin protein in the mutant gastric carcinoma tissues compared with normal mucosa tissues (Fig. 3). There were significant differences of
PTEN, PI3K and AKT proteins expressions between gastric carcinoma and normal gastric mucosa epithelium. A negative correlation was found between the expression of PTEN and PI3K or AKT proteins respectively, and there was a highly positive correlation between PI3K, AKT, MMP-2, MMP-9 and $\mathrm{NF}-\kappa \mathrm{Bp} 65$ protein expression.

\section{Discussion}

A series of genetic alterations, including activation of protooncogenes and inactivation of tumor suppressor genes, are an important process in human carcinogenesis. At present, research on structure alteration of tumor suppressor genes in tumor tissues and cancer cell lines, including point mutation, deletion, insertion, and cut point, indicates that the mutation rate of tumor suppressor genes is $33-50 \%$ in endometrial 
cancer, $25 \%$ in glioblastomas, $21 \%$ in ovarian cancer, $13 \%$ in prostate cancer, less than $5 \%$ in breast and thyroid cancer (9-17).

The PTEN gene was identified as a tumor suppressor gene, involved in cell survival, apoptosis prevention and growth stimulation. In addition, it regulates cell migration, modulates angiogenesis $(7,8)$ and, more recently, has been reported to be essential for maintaining chromosomal integrity through a physical association to centromere proteins (24). In fact, mutations and deletions of this gene have been described in a wide range of human cancers such as endometrial carcinomas, glioblastomas, and prostate cancers $(10,14,17)$. Germ-line mutations have also been identified in several rare autosomal dominant cancer predisposing conditions such as Cowden's disease and Bannayan-Zonana syndrome $(25,26)$. Recent studies indicate that mutations of the PTEN gene seem to be infrequent in gastric cancer (27-30), but the sample size analyzed was small in these investigations.

The mutations of PTEN gene are correlated with tumor progression and poor outcome in breast cancer and melanoma $(10,14)$. Therefore, the analysis of the PTEN gene mutations in gastric cancer might provide some information regarding tumor development and progression. In the current study, we examined the mutation status of the PTEN gene in gastric cancer in Shanghai, with a large number of samples, by direct sequencing all the 9 exons of PTEN, and found somatic mutations in 27 of $144(18.75 \%)$ primary tumor specimens, of which the mutation frequency is lower than some published reports (27). The exact reason remains unclear. As our tumor samples included all the histological subtypes, an environmental carcinogen prevailing in the geographic region might be responsible. Kang et al (31) pointed out that gastric carcinoma patients with silencing of the PTEN gene showed poor prognosis, and inactivation of the PTEN gene may play a vital role in the development and progression of gastric cancer. Also, the aberrant promoter methylation is suggested to be a major mechanism in the silencing of this gene $(31,32)$. Moreover, we found that mutational patterns of the PTEN gene were scattered on exon $1-9$, which is different from a former study resulting in clustering on exon 2-6 (27); with the mutation hot spots at codons $36,75,232$ and 393 , leading to missense mutations on codons 36,75 and 393 , and nonsense mutations on codon 232. Herein, mutations at codons 36, 75 and 393 might have a crucial role in the carcinogenesis or progression of gastric cancer. The result showed that there might be some unique characteristic of PTEN gene inactivation mechanism in the Shanghai population.

The status of PTEN gene mutation was significantly relevant to the pTNM staging and the degree of cell differentiation. PTEN mutation rate was significantly higher at pTMN stages III and IV than at stages I and II $(\mathrm{P}<0.005)$. Furthermore, the mutation rate was higher in poorly differentiated gastric cancer than in well and moderately differentiated pathological types $(\mathrm{P}<0.05)$. These results suggest that PTEN may play an important role in regulation of infiltration and metastasis of gastric cancer, and PTEN gene might be a prognostic biomarker of gastric cancer $(5,33,34)$.

In addition, we validated the regulation pathway of PTEN gene by immunoblotting. The mutations of PTEN gene really reduced PTEN protein expression in gastric cancer. In the development and progress of gastric carcinoma, PI3K and PTEN may counteract each other $(19,30)$, and the loss of PTEN protein expression may be related with the overexpression of PI3K, AKT, MMP-2, MMP-9 and NF-кBp65 protein. PI3K and AKT protein may cooperate to promote malignant progress of gastric carcinoma. E-cadherin protein was down-regulated in tumor tissues, which was negatively related with PI3K and AKT. With reduced expression of PTEN, the overexpression of PI3K and AKT might inhibit E-cadherin expression, highly promote expression of MMP-2, MMP-9 and NF-кBp65, thereby participated in the progress, invasion and metastasis of gastric cancer. It was reported that inactivation of PTEN induces infiltration and metastasis of tumors (35-39).

We, therefore, suggest that in gastric cancers inactivation of the PTEN gene by mutation may contribute to its downregulation besides hypermethylation of the PTEN promoter $(7,31)$. Nevertheless, the actual role of PTEN expression in patients with gastric cancer needs further investigation for confirmation. In contrast to most identified mutations of PTEN within exons 5-9, however, the specific mutation spectrum from our analysis is located within exons 1, 2, 4, 7 and 9. Consequently, these controversial results concerning the mechanism of the PTEN gene alterations and need further investigation to elucidate the viewpoint. In addition, we also found a mutation in intron 6 in one of 144 gastric cancers, and whether this mutation in the intron affects transcriptional or post-transcriptional modulation has still to be investigated.

Collectively, these results indicated that the mutations of the PTEN gene did not occur at a significant rate in gastric cancer in Shanghai, but the mutation hot spots suggested PTEN might have an important role in the pathogenesis and development of the tumor. Inactivation of PTEN induces infiltration and metastasis of gastric cancer through the overexpression of PI3K, AKT, MMP-2, MMP-9 and NF$\kappa B p 65$. Thus, clarifying the role of PTEN in the development and progression of gastric cancer will be helpful to comprehend the mechanism of gastric tumorigenesis. PTEN gene status might be considered as an indicator for the pathophysiological behavior of gastric cancer.

\section{Acknowledgements}

This research was supported by a grant from the Science and Technology Council of Shanghai, China (No.07ZR14064). We thank Professor Qian Zhao and Mrs. Ci-Xiang Zhou, Department of Pathophysiology, School of Medicine, Shanghai Jiao Tong University, for their excellent technical assistance.

\section{References}

1. Fan D, Zhang X, Chen X, et al: Bird's-eye view on gastric cancer research of the past 25 years. J Gastroenterol Hepatol 20: 360-365, 2005.

2. Wu CX, Zheng Y, Bao PP, et al: Pattern of changing incidence of gastric cancer and its time trend in Shanghai. J Surg Concepts Pract 13: 24-29, 2008.

3. Wang X, Wu CX, Zheng $\mathrm{Y}$ and Wang JJ: Time trends and characteristics of gastric cancer incidence in urban Shanghai. Chin J Epidemiol 28: 875-880, 2007. 
4. Lima EM, Araújo JJ, Harada ML, Assumpção PP, Burbano RR and Casartelli C: Molecular study of the tumour suppressor gene PTEN in gastric adenocarcinoma in Brazil. Clin Exp Med 5: 129-132, 2005

5. Oki E, Kakeji Y, Baba H, et al: Impact of loss of heterozygosity of encoding phosphate and tensin homolog on the prognosis of gastric cancer. J Gastroenterol Hepatol 21: 814-818, 2006.

6. Groszer M, Erickson R, Adams DS, et al: Negative regulation of neural stem/progenitor cell proliferation by the PTEN tumor suppressor gene in vivo. Science 294: 2186-2189, 2001.

7. Stiles BL: Phosphatase and tensin homologue deleted on chromosome 10: extending its PTENtacles. Int J Biochem Cell Biol 41: 757-761, 2009.

8. Raftopoulou M, Manneville SE, Self A, Nicholls S and Hall A: Regulation of cell migration by the $\mathrm{C} 2$ domain of the tumor suppressor PTEN. Science 303: 1179-1181, 2004.

9. Orrico A, Galli L, Buoni S, Orsi A, Vonella G and Sorrentino V: Novel PTEN mutations in neurodevelopmental disorders and macrocephaly. Clin Genet 75: 195-198, 2009.

10. Li J, Yen C, Liaw D, et al: PTEN, a putative protein tyrosine phosphatase gene mutated in human brain, breast and prostate cancer. Science 275: 1943-1947, 1997.

11. Bose K, Crane A, Hibshoosh H, Mansukhani M, Sandweis L and Parsons R: Reduced expression of PTEN correlates with breast cancer progression. Hum Pathol 33: 405-409, 2002.

12. Vranic S, Bilalovic N, Lee LM, Kruslin B, Lilleberg SL and Gatalica Z: PIK3CA and PTEN mutations in adenoid cystic carcinoma of the breast metastatic to kidney. Hum Pathol 38: 1425-1431, 2007.

13. Kolasa IK, Rembiszewska A, Jankowska AJ, DansonkaMieszkowska A, Lewandowska AM, Konopka B and Kupryjanczyk J: PTEN mutation, expression and $\mathrm{LOH}$ at its locus in ovarian carcinomas, Relation to TP53, K-RAS and BRCA1 mutations. Gynecol Oncol 103: 692-697, 2006.

14. Tunca B, Bekar A, Cecener G, et al: Impact of novel PTEN mutations in Turkish patients with glioblastoma multiforme. J Neurooncol 82: 263-269, 2007.

15. Marsit CJ, Zheng SC, Aldape K, Hinds PW, Nelson HH, Wiencke JK and Kelsey KT: PTEN expression in non-small cell lung cancer: evaluating its relation to tumor characteristics, allelic loss and epigenetic alteration. Hum Pathol 36: 768-776, 2005.

16. Marty B, Maire V, Gravier E, et al: Frequent PTEN genomic alterations and activated phosphatidylinositol 3-kinase pathway in basal-like breast cancer cells. Breast Cancer Res 10: R101, 2008.

17. Bansal N, Yendluri V and Wenham RM: The molecular biology of endometrial cancers and the implications for pathogenesis, classification and targeted therapies. Cancer Control 16: 8-13, 2009.

18. Teng Y, Sun AN, Pan XC, Yang G, Yang LL, Wang MR and Yang X: Synergistic function of Smad4 and PTEN in suppressing forestomach squamous cell carcinoma in the mouse. Cancer Res 66: 6972-6981, 2006.

19. Perrone F, Lampis A, Orsenigo M, et al: PI3KCA/PTEN deregulation contributes to impaired responses to cetuximab in metastatic colorectal cancer patients. Ann Oncol 20: 84-90, 2009.

20. Danielsen SA, Lind GE, Bjørnslett M, Meling GI, Rognum TO, Heim S and Lothe RA: Novel mutations of the suppressor gene PTEN in colorectal carcinomas stratified by microsatellite instability and TP53 mutation status. Hum Mutat 29: 252-262, 2008.

21. Wang L, Wang WL, Zhang Y, Guo SP, Zhang J and Li QL: Epigenetic and genetic alterations of PTEN in hepatocellular carcinoma. Hepatol Res 37: 389-396, 2007.

22. Japanese Research Society for Gastric Cancer: The general rules for the gastric cancer study. Part I. Clinical, surgical and conclusive findings. Part II. Histological findings. Kanehara Co., Tokyo, pp2-46, 1995.
23. Sambrook J, Fritsch EF and Maniatis T: Molecular cloning: a laboratory manual. Cold Spring Harbor Laboratory, New York, pp622-634, 1989.

24. Shen WH, Balajee AS, Wang J, Wu H, Eng C, Pandolfi PP and Yin Y: Essential role for nuclear PTEN in maintaining chromosomal integrity. Cell 128: 157-170, 2007.

25. Pezzolesi MG, Lim Y, Zhoum X-P, Pilarski R, Shen L and Eng C: Mutation-positive and mutation-negative patients with Cowden and Bannayan-Riley-Ruvalcaba syndromes associated with distinct 10q haplotypes. Am J Hum Genet 79: 923-934, 2006.

26. Butler MG, Dasouki MJ, Zhou XP, Pastore M, Prior TW and Sommer A: Increasing knowledge of PTEN germline mutations: two additional patients with autism and macrocephaly. Am J Med Genet A 143: 589-593, 2007.

27. Wang JY, Huang TJ, Chen FM, Hsieh MC, Lin SR, Hou MF and Hsieh JS: Mutation analysis of the putative tumor suppressor gene PTEN/MMAC1 in advanced gastric carcinomas. Virchows Arch 442: 437-443, 2003.

28. Fei G, Ebert MP, Mawrin C, Leodolter A, Schmidt N, Dietzmann $\mathrm{K}$ and Malfertheiner P: Reduced PTEN expression in gastric cancer and in the gastric mucosa of gastric cancer relatives. Eur J Gastroenterol Hepatol 14: 297-303, 2002.

29. Guo CY, Xu XF, Wu JY and Liu SF: PCR-SSCP-DNA sequencing method in detecting PTEN gene mutation and its significance in human gastric cancer. World J Gastroenterol 14: 3804-3811, 2008

30. Yu HG, Ai YW, Yu LL, et al: Phosphoinositide 3-kinase/Akt pathway plays an important role in chemoresistance of gastric cancer cells against etoposide and doxorubicin induced cell death. Int J Cancer 122: 433-443, 2008.

31. Kang YH, Lee HS and Kim WH: Promoter methylation and silencing of PTEN in gastric carcinoma. Lab Invest 82: 285-291, 2002.

32. Hou P, Ji MJ and Xing MZ: Association of PTEN gene methylation with genetic alterations in the phosphatidylinositol 3-kinase/Akt signaling pathway in thyroid tumors. Cancer 113: 2440-2447, 2008.

33. Hwang PH, Kim SY, Lee JC, Kim SJ, Yi HK and Lee DY: PTEN/MMAC1 enhances the growth inhibition by anticancer drugs with down-regulation of IGF-II expression in gastric cancer cells. Exp Mol Med 37: 391-398, 2005.

34. McCubrey JA, Steelmana LS, Abrams SL, et al: Roles of the RAF/MEK/ERK and PI3K/PTEN/AKT pathways in malignant transformation and drug resistance. Adv Enzyme Regul 46: 249-279, 2006

35. Trotman LC, Wang X, Alimonti A, et al: Ubiquitination regulates PTEN nuclear import and tumor suppression. Cell 128: 141-156, 2007.

36. Scheper MA, Chaisuparat R, Nikitakis NG and Sauk JJ: Expression and alterations of the PTEN/AKT/mTOR pathway in ameloblastomas. Oral Dis 14: 561-568, 2008

37. Zheng HC, Takahashi H, Murai Y, Cui Z, Nomoto K, Tsuneyama $\mathrm{K}$ and Takano Y: Low expression of FHIT and PTEN correlates with malignancy of gastric carcinomas: tissuearray findings. Appl Immunohistochem Mol Morphol 15: 432-440, 2007.

38. Silva A, Yunes JA, Cardoso BA, et al: PTEN post-translational inactivation and hyperactivation of the PI3K/Akt pathway sustain primary $\mathrm{T}$ cell leukemia viability. J Clin Invest 118: 3762-3774, 2008

39. Wee S, Wiederschain D, Maira SM, et al: PTEN-deficient cancers depend on PIK3CB. Proc Natl Acad Sci USA 105: 13057-13062, 2008. 